\title{
Maximizing Water Use Efficiency for Some Plants by Treated Magnetic Water Technique under East Owainat Conditions
}

\author{
A. Abdel-Aziz ${ }^{1}$,Y.A. Arafa ${ }^{2}$ and A. Sadik ${ }^{1}$ \\ ${ }^{1}$ Soil Chemistry and Physics Department - Desert Research Center and ${ }^{2}$ Agricultural \\ Engineer Department, Faculty of Agriculture, Ain Shams University, Cairo, Egypt
}

T

HIS experiment was carried out during the winter season of 2015, at a private farm in East Owainat area, New valley Governorate, Egypt, to study the effect of magnetic field levels $\left(0,2000,4000\right.$ Gauas) and applied irrigation water regimes $\left(\mathrm{IR}_{100 \%}, \mathrm{IR}_{90 \%}, \mathrm{IR}_{80 \%}\right.$ and $\left.\mathrm{IR}_{70 \%}\right)$ under surface (SDI) and sub- surface drip (SSDI) on marketable yield, plant quality parameters, water use efficacy (WUE), irrigation water use efficiency (IWUE) and yield response factor (Ky) of lettuce (Lactuca Sativa L.) and potato (Solanum Tuberosum L.) crops. The experimental design was a split-split plot design with three replicates. The obtained results indicated that, the values of physical analyses of irrigation water were decreased with increasing MF levels except solubility. While, the values of chemical analyses of IR increased with increasing MF levels except SAR. Meanwhile, the values of $\left(\mathrm{Na}^{+}, \mathrm{K}^{+}, \mathrm{CL}^{-}\right.$and $\left.\mathrm{HCO}_{3}^{-}\right)$were recorded non significant at different MF levels. Also, the results revealed that the values of quality parameters for lettuce plant and potato tubers increased with increasing both MF levels and IR under SDI and SSDI except total sugar TS for plant lettuce. The values of lettuce and potato Ya under (MF= 4000 Gauss, IR $=100 \%$ and SSDI) treatment increased significantly by about 40 and $34 \%$ compared to those under control treatment $(\mathrm{MF}=0$ Gauss, $\mathrm{IR}=100 \%$ and $\mathrm{SDI})$. Moreover, the maximum values of WUE and IWUE for lettuce plant were 7.08 and $3.88 \mathrm{~kg} \mathrm{~m}^{-3}$ respectively, under MF= 4000 Gauss, IR=80\% and SSDI treatment. While, the maximum values of WUE and IWUE for potato tubers were 11.28 and $5.89 \mathrm{~kg} \mathrm{~m}^{-3}$, respectively, under $\mathrm{MF}=4000$ Gauss, $\mathrm{IR}=80 \%$ and SSDI treatment. This study shows that utilization of magnetized water technology may be considered a promising technique to improve both crops yield productivity and save irrigation water.

Kyewords: Water use efficiency, Magnetic field, Irrigation water use efficiency; East Owainat

\section{Introduction}

Magnetic water treatment remains a little known in the field of plants metabolism and water relations. One of the harmless technologies which is considered in recent years by researchers of the agricultural science to increase plant yield and also increase the water productivity through a magnetic field before irrigation (Maheshwari and Grewal, 2009). Thus, magnetized water treatment increases plant metabolism in terms of photosynthesis and water uptake (Yano et al., 2004). A plant's metabolism contains 90 to $95 \%$ of water which is a diamagnetic compound and the rest contains several para, ferro and diamagnetic metals and non-metals in minute forms (Charan, 2009). The interaction of magnetic fields with flowing water; they measure absorbance, $\mathrm{pH}$, TDS, EC, viscosity, surface tension and thermal conductivity for ordinary tap water before and after applying magnetic fields of strength 6560 $\mathrm{G}$ which were generated by proper arrangement of permanent magnet pieces around the pipe accommodating the flowing water. They found that physical properties of magnetized water were inspected with proper and precise measuring techniques. These include the $\mathrm{pH}$ which was increased by $12 \%$, while TDS and EC both decreased by $33 \%$ and $36 \%$, respectively. As well, the mechanical parameters like viscosity and surface tension decreased too by a factor of $23 \%$ and $18 \%$, respectively. Even, the thermal conductivity decreased by $16 \%$ (Hasaani et al., 2015). The magnetic treatment of irrigation water had a positive effect on decreasing salinity of the soil (ECe) after the harvest of plants. Values of relative change ( $\mathrm{Rc} \pm \%$ ) of soil salinity (Ece), sodium adsorption ratio (SAR), $\mathrm{Na}+, \mathrm{Cl}-$ and $\mathrm{SO} 2-4$ decreased while ( $\mathrm{Rc} \pm \%$ ) of $\mathrm{Ca}++, \mathrm{Mg}++$, and $\mathrm{K}+$ in the soil extraction , after harvesting, increased due to MWT under S1; S2 and S3, as compared with magnetized fresh water (Amer et al., 2014). The results showed that the $\mathrm{pH}$ significantly increased under different magnetic 
field strength, while EC and TDS significantly decreased by magnetic treatment under different magnetic field strength and time of treatment by $15.60 \%$ after $300 \mathrm{~min}$. The results demonstrated that the magnetic treatments improved plant height, yield $\left(\mathrm{kg} / \mathrm{m}^{2}\right)$, fruit length, fruit diameter, and leaves dry matter percentage of cucumber plant compared to control treatment (Shahin et al., 2016). Thus, the present results have shown that irrigation with MTW can be considered as one of the most valuable modern technologies that can assist in saving irrigation water and reducing salt accumulation in plants (Al-Khazan et al., 2011). The combinations between the application of magnetic water and water regimes at $60 \%$ or $55 \%$ enhanced water use efficiency, tubers quality and yield of potato. Thus, the use of magnetic water and irrigation at $55 \%$ or $60 \%$ of the field capacity can be recommended to enhance vegetative growth, yield, and the components of potato plants, reduce soil salinity and improve soil fertility (Ahmed and Abd El-Kader, 2016). However, the variable magnetic fields may affect the biological functions of organisms through changes of hormone concentrations, changes of enzyme functions or transport of ions through the cell membrane and through changes in DNA synthesis or transmission (Strasak et al., 2002). The growth and productivity of corn increased by water magnetism under both full and limited irrigation. Both of water use efficiency (WUE) and irrigation water use efficiency (IWUE) increased when irrigation water was magnetized particularly under water deficit conditions. Maximum WUE and IWUE were obtained when $\mathrm{ETa} / \mathrm{ETm}$ ratio was between 0.65-0.85. Average values of crop ET (ETc) calculated by BlaneyCriddle and Hargreaves equation can be used to estimate the amount of applied irrigation water because of the closeness of ETc values from ETa values. Crop response factor for corn decreased when magnetized water was used for irrigation. Most measured physical and chemical properties of water were slightly affected by magnetism (Aoda and Fattah, 2011).The highest average lettuce yield of 7.8 ton $\mathrm{da}^{-1}$ was obtained from the full-irrigation treatment $(\mathrm{Kp} 1=1.0)$. Significant differences were not observed between $\mathrm{Kp} 1=1.0$ and $\mathrm{Kp} 2=0.75$ treatments in terms of lettuce yield. Maximum irrigation water use efficiency and total water use efficiency were obtained from Kp $4=0.25$ treatment, respectively with 0.117 and 0.074 ton $\mathrm{da}^{-1} \mathrm{~mm}^{-1}$. Yield response factor (ky) was found to be 0.88 . The research results showed that a 7 day irrigation interval with $\mathrm{Kp} 2=0.75$ treatment could be used for irrigating lettuce under the unheated greenhouse conditions without any significant yield loss but increased water use efficiencies (Kirnak et al., 2016). Irrigating potato by drip irrigation with three levels $(100 \%, 75 \%$ and $50 \%$ of the basin evaporation) gained a significant increase in plant height, number of aerobic stems, leaf area, plant dry weight and total tubers yield by increased irrigation level (Al-Janaby, 2012). The effect of irrigation water level on the yield, tuber height, diameter, weight, dry matter, starch matter, the tuber number per plant and plant height were found significant. The highest yield was $36 \mathrm{t}$ $\mathrm{ha}^{-1}$. Crop yield response factor (ky) was found as 1.13. The highest values for water use efficiency (WUE) and irrigation water use efficiency (IWUE) were found to be 4.84 and $4.29 \mathrm{~kg} \mathrm{~m}^{-3}$ for the $\mathrm{K} 2 \mathrm{cp}=75 \%$ treatment. When water resources are scarce, it can be recommended that K2cp treatment is most suitable as a water application level for potato irrigation by drip irrigation under unheated greenhouse condition (Ayas, 2013).

This study aimed to investigate the effect of both magnetic field levels and applied irrigation water under surface and sub-surface drip irrigation on lettuce and potato crops production, quality growth parameters, actual evapotranspiration, water use efficiency and yield response factor.

\section{Materials and Methods}

\section{Experiments}

Field experiments were carried out in East Owainat area, New Valley Governorate, Egypt $\left(23^{\circ} 41^{`} \mathrm{~N}\right.$ : $29^{\circ} 26^{`}$ E. $54 \mathrm{~m}$ a.s.l) during the winter season of 2015. In split-split plot design with three replicates, the experimental was divided into 30 $\mathrm{m}^{2}$ plots; each bounded by $1.5 \mathrm{~m}$ wide barren to avoid horizontal infiltration. The obtained data were subjected to statistical analysis according to Snedecor and Cochran (1989) using Co-state software program. Figure 1 showed the lettuce (Lactuca sativa L.) and potato (Solanum tuberosum L.) cultivated using four defects of applied irrigation water $\left(\mathrm{IR}_{100 \%}, \mathrm{IR}_{90 \%}, \mathrm{IR}_{80 \%}\right.$ and $\left.\mathrm{IR}_{70 \%}\right)$ treated with three magnetic field levels (MF) (0, 2000 and 4000 Gauss) tested under surface (SDI) and sub-surface drip irrigation (SSDI).

Soil management practices were applied using doses of fertilizer as recommended by the Ministry of Agriculture and Land Reclamation.

The length $(\mathrm{L}) \mathrm{Cm}$, diameter (D) $\mathrm{Cm}$, total 


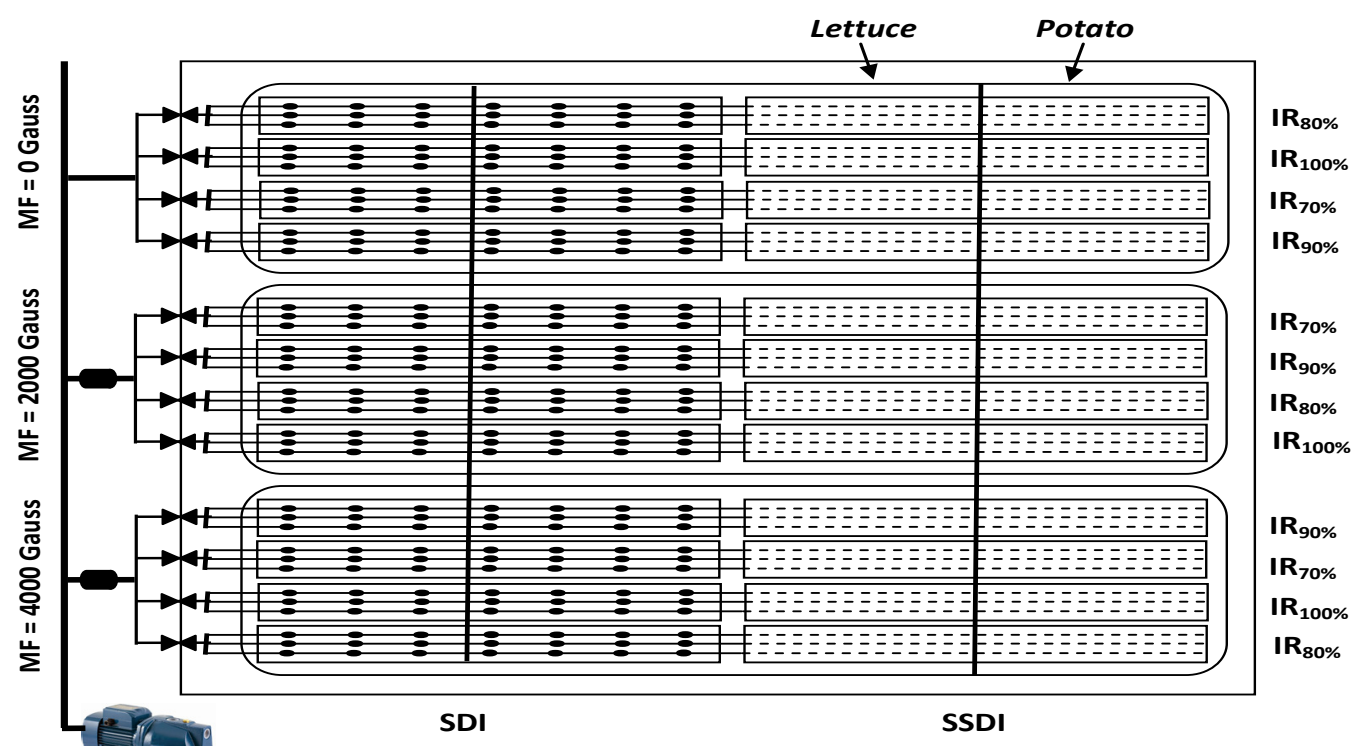

Fig. 1. Field experiment layout.

soluble solid (TSS) \%, vitamin C (Vc) mg 100 $\mathrm{g}^{-1} \mathrm{fw}$ and marketable yield (Ya) g/plant) were determined for lettuce plant. While, hight $(\mathrm{H})$ $\mathrm{Cm}$, diameter (D) $\mathrm{Cm}$, total soluble solid (TSS) $\%$, starch (S) \%, protein (P) \% and specific gravity (SG) were determined for potato tuber. Water use efficiency WUE $\left(\mathrm{kg} \mathrm{m}^{-3}\right)$, irrigation water use efficiency IWUE $\left(\mathrm{kg} \mathrm{m}^{-3}\right)$ and actual evapotranspiration ETa $(\mathrm{mm})$, were calculated at different MF levels for all IR under SDI and SSDI for lettuce and potato plots.

- Starch percentage was determined according to the method described by Dogras et al. (1991).
- Total soluble solids (TSS \%) was determined using the hand refractmeter.

- $\quad$ Specific gravity of potato tubers $\mathrm{SG}=$ Wair / (Wair - Wwater) (Nessen, 1967)

where: Wair : weight of tubers in air, g.

Wwater: weight of tubers in water, $\mathrm{g}$.

Soil characteristics

Soil samples were collected for some physical and chemical soil characteristics. The methodological procedures were according to methods described by Page et al. (1982) and Klute 1986) (Tables 1\&2)

TABLE 1. Some physical characteristics of experimental soil

\begin{tabular}{ccccccccccccc}
\hline $\begin{array}{c}\text { Soil } \\
\text { depth } \\
\text { (cm) }\end{array}$ & $\begin{array}{c}\text { C. } \\
\text { sand }\end{array}$ & $\begin{array}{c}\text { Manticle size distribution \% } \\
\text { sand }\end{array}$ & F. sand & Silt & Clay & $\begin{array}{c}\text { Textural } \\
\text { class }\end{array}$ & $\begin{array}{c}\text { OM } \\
\mathbf{\%}\end{array}$ & $\begin{array}{c}\boldsymbol{\rho}_{\boldsymbol{b}} \\
\mathbf{g} / \mathbf{c m}^{\mathbf{3}}\end{array}$ & $\begin{array}{c}\text { Ks } \\
\mathbf{c m} / \mathbf{h}\end{array}$ & $\begin{array}{c}\text { FC } \\
\mathbf{\%}\end{array}$ & $\begin{array}{c}\text { WP } \\
\mathbf{\%}\end{array}$ & $\begin{array}{c}\text { AW } \\
\mathbf{\%}\end{array}$ \\
\hline $\mathbf{0 - 1 5}$ & 12.61 & 63.24 & 4.67 & 11.42 & 8.06 & LS & 0.45 & 1.51 & 9.67 & 10.29 & 3.12 & 7.17 \\
$\mathbf{1 5 - 3 0}$ & 13.38 & 62.25 & 5.13 & 11.26 & 7.98 & LS & 0.39 & 1.53 & 10.05 & 9.87 & 3.04 & 6.83 \\
$\mathbf{3 0 - 4 5}$ & 13.82 & 61.61 & 5.46 & 11.18 & 7.93 & LS & 0.37 & 1.54 & 10.43 & 9.43 & 2.98 & 6.45 \\
\hline
\end{tabular}

TABLE 2. Some chemical characteristics of experimental soil

\begin{tabular}{|c|c|c|c|c|c|c|c|c|c|c|c|c|}
\hline \multirow{2}{*}{ 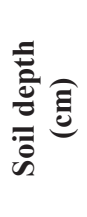 } & \multirow{2}{*}{ 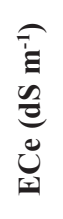 } & \multirow{2}{*}{$\sqrt{2}$} & \multirow{2}{*}{$\partial^{0}$} & \multirow{2}{*}{ 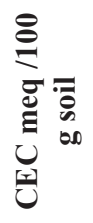 } & \multicolumn{8}{|c|}{ Soluble ions (meq/l) in the saturated soil paste } \\
\hline & & & & & $\stackrel{+\pi}{n^{\pi}}$ & 声 & \begin{tabular}{l}
+ \\
\multirow{\sigma}{*}{} \\
$\tilde{\sigma}$
\end{tabular} & $\sum^{+\infty}$ & $\dot{U}$ & $\stackrel{0}{0}^{m}$ & $e^{\prime}$ & $\mathfrak{o}^{+}$ \\
\hline 0-15 & 1.94 & 8.02 & 2.51 & 6.56 & 9.71 & 1.06 & 5.45 & 3.18 & 9.45 & 2.67 & - & 7.28 \\
\hline $15-30$ & 2.06 & 7.98 & 2.57 & 6.09 & 9.95 & 1.31 & 5.78 & 3.56 & 10.17 & 2.89 & - & 7.54 \\
\hline $30-45$ & 2.11 & 7.96 & 2.74 & 5.84 & 10.07 & 1.5 & 5.85 & 3.68 & 10.21 & 3.03 & - & 7.86 \\
\hline
\end{tabular}


Irrigation water characteristics

Physical and chemical analyses of the irrigation water without magnetic field $(\mathrm{MF}=0)$ were measured according to methods described by Ayers and westcot (1994) (Tables 3\&4).
Reference evapotranspiration ETo

The reference evapotranspiration (ETo) shown in Table 5 was calculated using the Cropwate (8) software based on Penman-Monteith equation FAO 56 method (Allen et al., 1998).

TABLE 3. Some physical analysis for irrigation water under no $\mathrm{MF}=0$ treated

\begin{tabular}{|c|c|c|c|c|c|c|c|c|}
\hline$\frac{\mathscr{E}}{\bar{E}}$ & 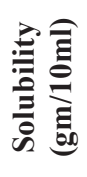 & $\frac{0}{\stackrel{0}{0}}$ & 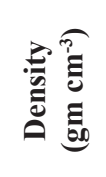 & 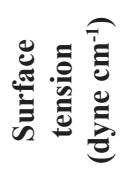 & 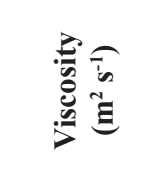 & 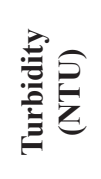 & 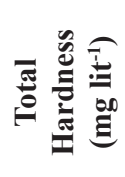 & 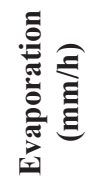 \\
\hline mean & 3.18 & 1.3324 & 1.0056 & 72.43 & $0.827 \times 10^{-6}$ & 761.12 & 225.36 & 0.542 \\
\hline
\end{tabular}

TABLE 4. Some chemical analysis for irrigation water under no $M F=0$ treated

\begin{tabular}{|c|c|c|c|c|c|c|c|c|c|c|c|c|}
\hline \multirow{2}{*}{ Samples } & \multirow{2}{*}{ pH } & \multirow{2}{*}{$\begin{array}{c}\text { EC } \\
\mathrm{dS} / \mathrm{m}\end{array}$} & \multirow{2}{*}{$\begin{array}{c}\text { TDS } \\
\text { (ppm) }\end{array}$} & \multirow{2}{*}{ SAR } & \multicolumn{4}{|c|}{ Soluble cations, meq/l } & \multicolumn{4}{|c|}{ Soluble anions , meq/l } \\
\hline & & & & & $\mathbf{N a}^{+}$ & $\mathbf{K}^{+}$ & $\mathbf{C a}^{++}$ & $\mathbf{M g}^{++}$ & $\mathbf{C} \mathbf{L}^{-}$ & $\mathrm{HCO}_{3}^{-}$ & $\mathrm{CO}_{3}=$ & $\mathrm{SO}_{4}=$ \\
\hline mean & 7.39 & 1.53 & 489.60 & 6.97 & 9.76 & 0.42 & 2.90 & 1.04 & 7.89 & 3.17 & - & 2.48 \\
\hline
\end{tabular}

TABLE 5. Calculation reference evapotranspiration $\left(\mathrm{mm} \mathrm{day}^{-1}\right)$ through lettuce and potato growth period.

\begin{tabular}{rccccc}
\hline Month & October & November & December & January & February \\
\hline${\text { ETo, } \text { mm day }^{-1}}^{C}$ & 9.76 & 6.73 & 5.68 & 5.16 & 6.48 \\
\hline
\end{tabular}

Crop evapotranspiration (ETc)

The crop evapotranspiration (ETc) shown in Table 6 was calculated using the equation:

Leaching requirement $L R$

- $\quad E T C=K c_{\mathrm{FAO}} . \mathrm{ETO}$

$\left(\mathrm{mm} \mathrm{day}{ }^{-1}\right)$

1998) (Allen et al.,

Where: $\mathrm{Kc}_{\mathrm{FAO}}$ : crop coefficient from FAO No.(56). ETo : reference crop evapotranspiration, $\mathrm{mm} \mathrm{dav}^{-1}$.

TABLE 6. Calculation crop evapotranspiration $\left(\mathrm{mm} \mathrm{day}^{-1}\right)$ through lettuce and potato growth period.

\begin{tabular}{|c|c|c|c|c|c|c|}
\hline Crops & Stages & Initial & Develop. & Mid & Late & Seasonal \\
\hline \multirow{4}{*}{ Lettuce } & Period length (day) & 25 & 35 & 30 & 10 & 100 \\
\hline & $\mathrm{Kc}_{\mathrm{FAO}}(-)$ & 0.70 & 0.85 & 1.00 & 0.95 & -------- \\
\hline & ETo (mm) & 216.73 & 220.85 & 163.64 & 51.60 & 652.82 \\
\hline & $\operatorname{ETc}_{100 \%}(\mathrm{~mm})$ & 151.71 & 187.72 & 163.64 & 49.02 & 552.09 \\
\hline \multirow{4}{*}{ Potato } & Period length (day) & 25 & 30 & 30 & 30 & 115 \\
\hline & $K \mathbf{c}_{\mathrm{FAO}}(-)$ & 0.50 & 0.83 & 1.15 & 0.75 & -------- \\
\hline & ETo $(\mathbf{m m})$ & 216.73 & 192.45 & 166.24 & 164.04 & 739.46 \\
\hline & $\mathbf{E T c}_{100 \%}(\mathbf{m m})$ & 108.37 & 159.73 & 191.18 & 123.03 & 582.31 \\
\hline
\end{tabular}

The leaching requirement LR was calculated by using the equation:

- $\mathrm{LR}=\quad \mathrm{EC}_{\mathrm{w}} /\left(5\left(\mathrm{EC}_{\mathrm{e}}\right)-\mathrm{EC}_{\mathrm{w}}\right) \times 100$

1998) (Allen et al.,

Where: ECw : electrical conductivity of the irrigation water, $\mathrm{dS} \mathrm{m}^{-1}$. ECe : average electrical conductivity of the soil solution extract, $\mathrm{dS} \mathrm{m}^{-1}$. 
Applied irrigation water IR

The amounts of applied irrigation water (IR) for lettuce and potato crops shown in Table 7 were calculated using the equation:

- IR100, 90, 80, 70\%= $(\mathrm{ETc}-\mathrm{pe}) \mathrm{Kr} / \mathrm{Ea})+\mathrm{LR}$

(mm period-1)

(Keller and Karmeli, 1974)

where: $\mathrm{Kr}$ :correction factor for limited wetting at lettuce and potato percent round coverage by canopy $80 \%, \mathrm{Kr}=0.90$. (Smith, 1992).

Ea : irrigation efficiency for surface drip (85\%) (Allen et al., 1998).

Pe : effective rainfall, $0 \mathrm{~mm}$.

LR : leaching requirements, under salinity levels of irrigation water $(0.17 \mathrm{x} \mathrm{ETc}), \mathrm{mm}$.

TABLE 7. Calculation applied irrigation water (IR), $\mathrm{mm}$ for lettuce and potato.

\begin{tabular}{|c|c|c|c|c|c|c|}
\hline \multirow{3}{*}{ Crops } & \multirow{3}{*}{$\begin{array}{c}\text { IR } \\
(\%)\end{array}$} & \multicolumn{5}{|c|}{ Applied Irrigation water (mm) } \\
\hline & & \multicolumn{5}{|c|}{ Growth Stages } \\
\hline & & Initial & Development & Mid & Late & Seasonal \\
\hline \multirow{4}{*}{ Lettuce } & 100 & 187.00 & 231.38 & 201.70 & 60.42 & 680.50 \\
\hline & 90 & 168.30 & 208.24 & 181.53 & 54.38 & 612.45 \\
\hline & 80 & 149.60 & 185.10 & 161.36 & 48.34 & 544.40 \\
\hline & 70 & 130.90 & 161.97 & 141.19 & 42.29 & 476.35 \\
\hline \multirow{4}{*}{ Potato } & 100 & 133.57 & 196.89 & 235.64 & 151.65 & 717.75 \\
\hline & 90 & 120.21 & 177.20 & 212.08 & 136.48 & 645.97 \\
\hline & 80 & 106.86 & 157.51 & 188.51 & 121.32 & 574.2 \\
\hline & 70 & 93.50 & 137.82 & 164.95 & 106.15 & 502.42 \\
\hline
\end{tabular}

- Actual evapotranspiration ETa $=(\mathrm{M} 2 \%-\mathrm{M} 1 \%) / 100$. db . D $\quad(\mathrm{mm})$

(Doorenbos and Pruitt, 1984)

where: M2 : moisture content after irrigation $\%$.

M1 : moisture content before irrigation $\%$.

$\mathrm{db} \quad$ : specific density of soil .

D : mean depth, mm.

- Water use efficiency WUE $=\mathrm{Ya} / \mathrm{ETa}\left(\mathrm{kg} \mathrm{m}^{-3}\right)($ Howell et al., 2001)

where: Ya : actual yield of the crop, $\left(\mathrm{kg} \mathrm{fed}^{-1}\right)$.

- Irrigation water use efficiency IWUE $=$ Ya $/$ IR $\left(\mathrm{kg} \mathrm{m}^{-3}\right)($ Michael, 1978)

where: IR : seasonal amounts of applied irrigation water, (m3), Table (7).

\section{$\underline{\text { Results and Discussion }}$}

Effect of MF levels on physical and chemical for irrigation water

Data in Table 8 reported that the values of physical analyses of irrigation water (IR) (refractive index, density $\left(\mathrm{gm} \mathrm{cm}^{-3}\right)$, surface tension (dyne $\left.\mathrm{cm}^{-1}\right)$, viscosity $\left(\times 10^{-6} \mathrm{~m}^{2} \mathrm{~s}^{-1}\right)$, turbidity (NTU), total hardness $\left(\mathrm{mg} \mathrm{lit}^{-1}\right)$ and evaporation $\left(\mathrm{mm} \mathrm{h}^{-1}\right)$ decreased with increasing magnetic field levels (MF) except solubility $(\mathrm{gm} / 10 \mathrm{ml})$ which was recorded increased with increasing MF levels. The minimum values of physical analyses were $(1.3323,1.0048$ gm cm${ }^{-3}, 68.75$ dyne $\mathrm{cm}^{-1}, 0.687 \times 10^{-6} \mathrm{~m}^{2} \mathrm{~s}^{-1}$, $645.31 \mathrm{NTU}, 187.53 \mathrm{mg} \mathrm{lit}^{-1}$ and $0.449 \mathrm{~mm}$ $\mathrm{h}^{-1}$ ), respectively, except solubility which was (3.46 gm/10ml) under MF= 4000 Gauss. While, the maximum values were $(1.3324,1.0056$ gm cm${ }^{-3}, 72.43$ dyne $\mathrm{cm}^{-1}, 0.827 \times 10^{-6} \mathrm{~m}^{2} \mathrm{~s}^{-1}$, $761.12 \mathrm{NTU}, 225.36 \mathrm{mg} \mathrm{lit}^{-1}$ and $0.542 \mathrm{~mm} \mathrm{~h}^{-1}$ ), respectively, except solubility which was (3.18 $\mathrm{gm} / 10 \mathrm{ml}$ ) under $\mathrm{MF}=0$ Gauss. These results are harmonious with those obtained by Hasaani et al., 2015). 
TABLE 8. Effect of MF levels on physical analyses for irrigation water

\begin{tabular}{ccccc}
\hline Physical proprieties & \multicolumn{3}{c}{ Magnetic Field (Gauss) } & LSD (0.05\%) \\
\cline { 2 - 4 } Solubility $(\mathbf{g m} / \mathbf{1 0 m l})$ & 3.18 & 3.34 & $\mathbf{4 0 0 0}$ & $\mathbf{0 . 0 2}$ \\
Refractive index & 1.3324 & 1.3323 & 1.3323 & 1.17 \\
Density $\left(\mathrm{gm} \mathrm{cm}^{-3}\right)$ & 1.0056 & 1.0053 & 1.0048 & 0.0006 \\
Surface tension $\left(\right.$ dyne cm $\left.^{-1}\right)$ & 72.43 & 71.98 & 68.75 & 0.83 \\
Viscosity $\left(\times 10^{-6} \mathrm{~m}^{2} \mathrm{~s}^{-1}\right)$ & 0.827 & 0.762 & 0.687 & 0.065 \\
Turbidity $(\mathrm{NTU})$ & 761.12 & 708.56 & 645.31 & 4.29 \\
Total Hardness $\left(\mathrm{mg} \mathrm{lit}^{-1}\right)$ & 225.36 & 203.09 & 187.53 & 3.05 \\
Evaporation $\left(\mathrm{mm} \mathrm{h}^{-1}\right)$ & 0.542 & 0.497 & 0.449 & 2.41 \\
\hline
\end{tabular}

Moreover, Data in Table 9 concluded that the values of chemical analyses of IR ( $\mathrm{pH}$, electricconductivity $\mathrm{Ec}\left(\mathrm{dS} \mathrm{m}^{-1}\right)$, total dissolved salts TDS (ppm), $\mathrm{Ca}^{++}, \mathrm{Mg}^{++}$and $\mathrm{SO}_{4}{ }^{\circ}$ ) increased with increasing MF levels except SAR was recorded decreased with increasing MF levels. The maximum values of chemical analyses were (7.45, $1.56 \mathrm{dS} \mathrm{m}^{-1}, 499.20 \mathrm{ppm}, 2.93,1.06$ and 2.53), respectively, except SAR was 6.92 under $\mathrm{MF}=4000$ Gauss. While, the minimum values were $\left(7.39,1.53 \mathrm{dS} \mathrm{m}^{-1}, 489.60 \mathrm{ppm}, 2.90,1.04\right.$

TABLE 9. Effect of MF levels on chemical analyses for irrigation water

\begin{tabular}{|c|c|c|c|c|}
\hline \multirow{2}{*}{ Chemical proprieties } & \multicolumn{3}{|c|}{ Magnetic Field (Gauss) } & \multirow{2}{*}{ LSD $(0.05 \%)$} \\
\hline & 0 & 2000 & 4000 & \\
\hline $\mathrm{pH}$ & 7.39 & 7.42 & 7.45 & 0.05 \\
\hline$\underline{\mathrm{Ec}}\left(\mathrm{dS} \mathrm{m}^{-1}\right)$ & 1.53 & 1.54 & 1.56 & 0.02 \\
\hline TDS (ppm) & 489.60 & 492.80 & 499.20 & 1.17 \\
\hline$\underline{\text { SAR }}$ & 6.97 & 6.92 & 6.92 & 0.03 \\
\hline$\underline{\mathrm{Na}}^{ \pm}$ & 9.76 & 9.76 & 9.76 & N.S \\
\hline $\mathbf{K}^{+}$ & 0.42 & 0.42 & 0.42 & N.S \\
\hline$\underline{\mathrm{Ca}}^{++}$ & 2.90 & 2.91 & 2.93 & 0.03 \\
\hline$\underline{\mathrm{Mg}^{+\underline{+}}}$ & 1.04 & 1.05 & 1.06 & 0.01 \\
\hline$\underline{\mathrm{CL}}=$ & 7.89 & 7.89 & 7.89 & N.S \\
\hline $\mathrm{HCO}_{3}=$ & 3.17 & 3.17 & 3.17 & N.S \\
\hline$\underline{\mathrm{CO}}_{\underline{3}} \equiv$ & - & - & - & - \\
\hline$\underline{\mathrm{SO}}_{4} \equiv$ & 2.48 & 2.51 & 2.53 & 0.04 \\
\hline
\end{tabular}

Effect of MF and IR under IS on studied quality parameters of crops

Lettuce

Data in Fig. $2 \& 3$ showed that the values of studied quality parameters for lettuce plant (length $(\mathrm{L}) \mathrm{Cm}$, diameter (D) $\mathrm{Cm}$, total soluble solid (TSS) \%, vitamin C (VC) mg $100 \mathrm{~g}^{-1} \mathrm{fw}$ and marketable yield (Ya) g/plant) increased with increasing both magnetic field levels (MF) and applied irrigation water (IR). While, total sugar (TS) \% fw increased with increasing MF and decreased with increasing IR under surface and 2.48), respectively, except SAR which was 6.97 under MF $=0$ Gauss. Meanwhile, Data in the same table showed that the values of $\left(\mathrm{Na}^{+}, \mathrm{K}^{+}, \mathrm{CL}-\right.$ and $\mathrm{HCO}_{3}^{-}$) were not significant at different MF levels. One can explain the result as; when water flows through the magnetic field, the nuclei of its atoms are polarized, this polarization makes the atoms behave as tiny magnets with north and south poles. These results are in agreement with Amer et al. (2014) and Hasaani et al. (2015).
(SDI) and sub-surface drip (SSDI) irrigation. The maximum values of lettuce plant L, D, TSS, VC and Ya were $(17.58 \mathrm{~cm}, 24.74 \mathrm{~cm}, 2.19 \%, 19.65$ $\mathrm{mg} 100 \mathrm{~g}^{-1} \mathrm{fw}$ and $\left.425.75 \mathrm{~g} / \mathrm{plant}\right)$, respectively, except TS which was $(3.83 \% \mathrm{fw})$ under $\mathrm{MF}=4000$ Gauss, IR $=100 \%$ and SSDI treatment. While, the minimum values were $(34.31 \mathrm{~cm}, 69.05 \mathrm{~cm}$,

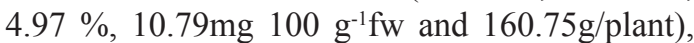
respectively, except TS which was $(3.05 \% \mathrm{fw})$ under $\mathrm{MF}=0$ Gauss, $\mathrm{IR}=70 \%$ and SDI treatment. The values of lettuce plant L, D, TSS, TS, Vc and Ya under $\mathrm{MF}=4000$ Gauss, $\mathrm{IR}=100 \%$ and SSDI 
treatment were recorded increased significantly by about $20,37,45,60,28$ and $52 \%$, respectively, compared to that under control treatment $(\mathrm{MF}=$ 0 Gauss, $\mathrm{IR}=100 \%$ and SDI). These results are similar to those reported by Shahin et al. (2016).

Moreover, Figures $1 \& 2$ revealed that the relationships between IR, $\mathrm{mm}$ and the studied quality parameters of lettuce plant were highly significant positively correlated with $\mathrm{MF}=0$ Gauss, L $\left(\mathrm{r}=0.996^{* *}\right)$, D $\left(\mathrm{r}=0.995^{* *}\right)$, TSS $\left(\mathrm{r}=0.996^{* *}\right), \mathrm{VC}\left(\mathrm{r}=0.996^{* *}\right)$ and $\mathrm{Ya}(\mathrm{r}=$ $\left.0.998^{* *}\right)$ under SDI. Also, L $\left(\mathrm{r}=0.997^{* *}\right)$, D (r $=0.994 * *), \operatorname{TSS}\left(\mathrm{r}=0.995^{* *}\right), \mathrm{VC}\left(\mathrm{r}=0.998^{* *}\right)$ and $\mathrm{Ya}\left(\mathrm{r}=0.996^{* *}\right)$ recorded highly significant positively correlated with $\mathrm{MF}=0$ Gauss under SSDI. While, the relationship between IR, $\mathrm{mm}$ and TS was highly significant negatively correlated with $\mathrm{MF}=0$ Gauss, $(\mathrm{r}=-0.992 * *)$ and $\left(\mathrm{r}=-0.998^{* *}\right)$ under SDI and SSDI, respectively. Meanwhile, the same relationships recorded significant positively correlated with $\mathrm{MF}=2000$ Gauss, L $\left(\mathrm{r}=0.955^{*}\right), \mathrm{D}\left(\mathrm{r}=0.987^{*}\right)$, TSS $(\mathrm{r}=$ $\left.0.954^{*}\right), \mathrm{VC}\left(\mathrm{r}=0.974^{*}\right)$ and $\mathrm{Ya}\left(\mathrm{r}=0.983^{*}\right)$ under SDI. Also, L $\left(r=0.961^{*}\right)$, D $\left(r=0.986^{*}\right)$, TSS $\left(r=0.963^{*}\right), \mathrm{VC}\left(\mathrm{r}=0.974^{*}\right)$ and $\mathrm{Ya}(\mathrm{r}=$ $\left.0.983^{*}\right)$ recorded significant positively correlated with $\mathrm{MF}=2000$ Gauss under SSDI. On the other hand, the relationship between IR, $\mathrm{mm}$ and TS was significant negatively correlated with $\mathrm{MF}=$ 2000 Gauss, $\left(r=-0.966^{*}\right)$ and $\left(r=-0.979^{*}\right)$ under SDI and SSDI, respectively. Finally, the relationships between IR, mm and studied quality parameters of lettuce plant were not significantly correlated with $\mathrm{MF}=4000$ Gauss, under SDI and SSDI. These results may be attributed to that magnetized water treatment increases plant metabolism in terms of photosynthesis and water uptake. These results are in agreement with Yano et al. (2004).

\section{Potato}

Data in Fig. 3\&4 showed that the values of the studied quality parameters for potato tuber (high (H) $\mathrm{Cm}$, diameter (D) $\mathrm{Cm}$, total soluble solid (TSS) \%, starch (S) \%, protein (P) \% and specific gravity (SG) increased with increasing both magnetic field levels (MF) and applied irrigation water (IR) under SDI and SSDI. The maximum values of potato tuber $\mathrm{H}, \mathrm{D}, \mathrm{TSS}, \mathrm{S}, \mathrm{P}$ and $\mathrm{SG}$ were $(9.55 \mathrm{~cm}, 9.02 \mathrm{~cm}, 4.45 \%, 17.52 \%, 2.46$ $\%$ and 1.079), respectively, under $\mathrm{MF}=4000$ Gauss, IR $=100 \%$, and SSDI treatment. While, the minimum values were $(5.04 \mathrm{~cm}, 4.56 \mathrm{~cm}$, $4.30 \%, 11.59 \%, 1.41 \%$ and 1.062 ) respectively, under $\mathrm{MF}=0$ Gauss, $\mathrm{IR}=70 \%$ and $\mathrm{SDI}$ treatment. The values of potato tuber $\mathrm{H}, \mathrm{D}, \mathrm{TSS}, \mathrm{S}, \mathrm{P}$ and $\mathrm{SG}$ under $\mathrm{MF}=4000$ Gauss, $\mathrm{IR}=100 \%$ and SSDI treatment increased significantly by about 29 , $35,1,51,32$ and $0.75 \%$, respectively, compared to those under control treatment $(\mathrm{MF}=0$ Gauss, $\mathrm{IR}=100 \%$ and SDI). These results agreed with that obtained by Al- Janaby (2012).

Moreover, Fig. $3 \& 4$ indicated that the relationships between IR, $\mathrm{mm}$ and studied quality parameters of potato tuber were highly significant positively correlated with $\mathrm{MF}=0$ Gauss, $\mathrm{H}(\mathrm{r}=$ $\left.0.997^{* *}\right), \mathrm{D}(\mathrm{r}=0.999 * *)$, TSS $(\mathrm{r}=0.993 * *)$, $\mathrm{S}(\mathrm{r}=0.994 * *), \mathrm{P}(\mathrm{r}=0.992 * *)$ and $\mathrm{SG}(\mathrm{r}=$ $\left.1.000^{* *}\right)$ under SDI. Also, H $\left(\mathrm{r}=0.999^{* *}\right)$, D (r $\left.=1.000^{* *}\right), \operatorname{TSS}\left(\mathrm{r}=0.996^{* *}\right), \mathrm{S}\left(\mathrm{r}=0.991^{* *}\right), \mathrm{P}$ $\left(\mathrm{r}=0.996^{* *}\right)$ and SG $\left(\mathrm{r}=0.996^{* *}\right)$ under SSDI. Meanwhile, the relationships revealed that they significant positively correlated with $\mathrm{MF}=$ 2000 Gauss, $\mathrm{H}\left(\mathrm{r}=0.950^{*}\right), \mathrm{D}(\mathrm{r}=0.952 *), \mathrm{S}$ $\left(\mathrm{r}=0.968^{*}\right)$ and $\mathrm{P}\left(\mathrm{r}=0.951^{*}\right)$ except $\mathrm{TSS}(\mathrm{r}=$ $\left.0.994^{* *}\right)$ and SG $\left(\mathrm{r}=0.997^{* *}\right)$ which were the highly significant positively correlated under SDI. Also, H $(r=0.962 *)$, D $\left(r=0.963^{*}\right)$, S ( $r$ $\left.=0.967^{*}\right)$ and $\mathrm{P}\left(\mathrm{r}=0.983^{*}\right)$ except TSS $(\mathrm{r}=$ $\left.0.996^{* *}\right)$ and SG $\left(\mathrm{r}=0.996^{* *}\right)$ were the highly significant positively correlated under SSDI. Generally, the relationships between IR, mm and studied quality parameters of potato tuber were not significantly correlated with $\mathrm{MF}=$ 4000 Gauss, except TSS $\left(r=0.994^{* *}\right)$ and SG $\left(\mathrm{r}=0.997^{* *}\right)$ which were the highly significant positively correlated, under SDI and SSDI. These results may be attributed to the plant's metabolism containing 90 to $95 \%$ of water which is a diamagnetic compound and the rest contains several para, ferro and diamagnetic metals and non-metals in minute forms according to Charan (2009).

\section{Effect of MF and IR under IS on marketable} yield of crops

Data in Tables 10\&11 reported that the values of marketable yield (Ya) for lettuce plant and potato tubers increased with increasing both MF levels and IR under SDI and SSDI. The maximum values of Ya for lettuce and potato crops were 8.17 and $13.21 \mathrm{Mg} \mathrm{fed}^{-1}$, respectively, under $\mathrm{MF}=4000$ Gauss, $\mathrm{IR}=100 \%$ and SSDI treatment. While, the minimum values were 3.25 and $5.13 \mathrm{Mg} \mathrm{fed}^{-1}$ for both crops under $\mathrm{MF}=0$ Gauss, $\mathrm{IR}=70 \%$ and SDI treatment. 

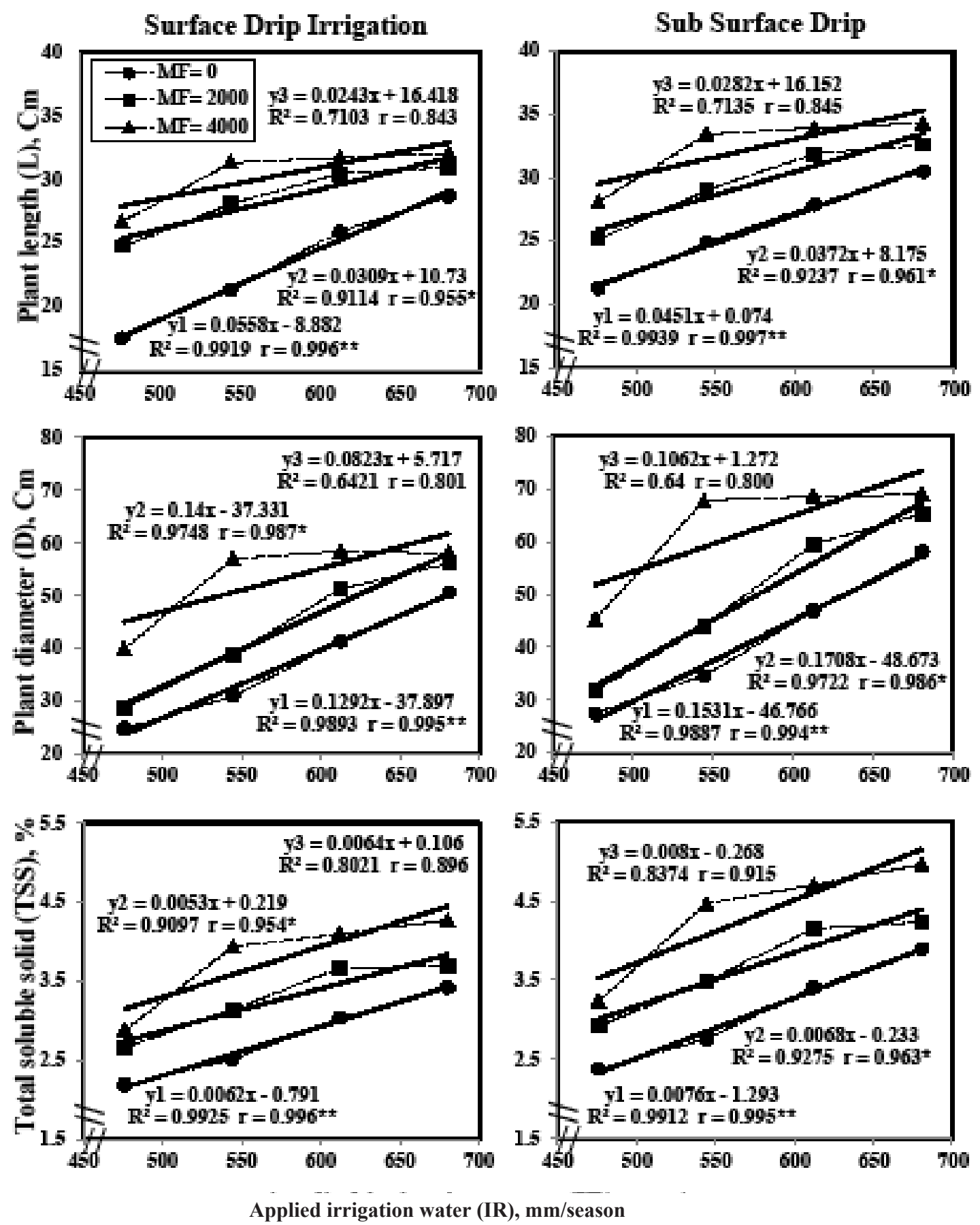

Fig.2. Relationships between applied irrigation water (IR) and studied quality parameters of lettuce 

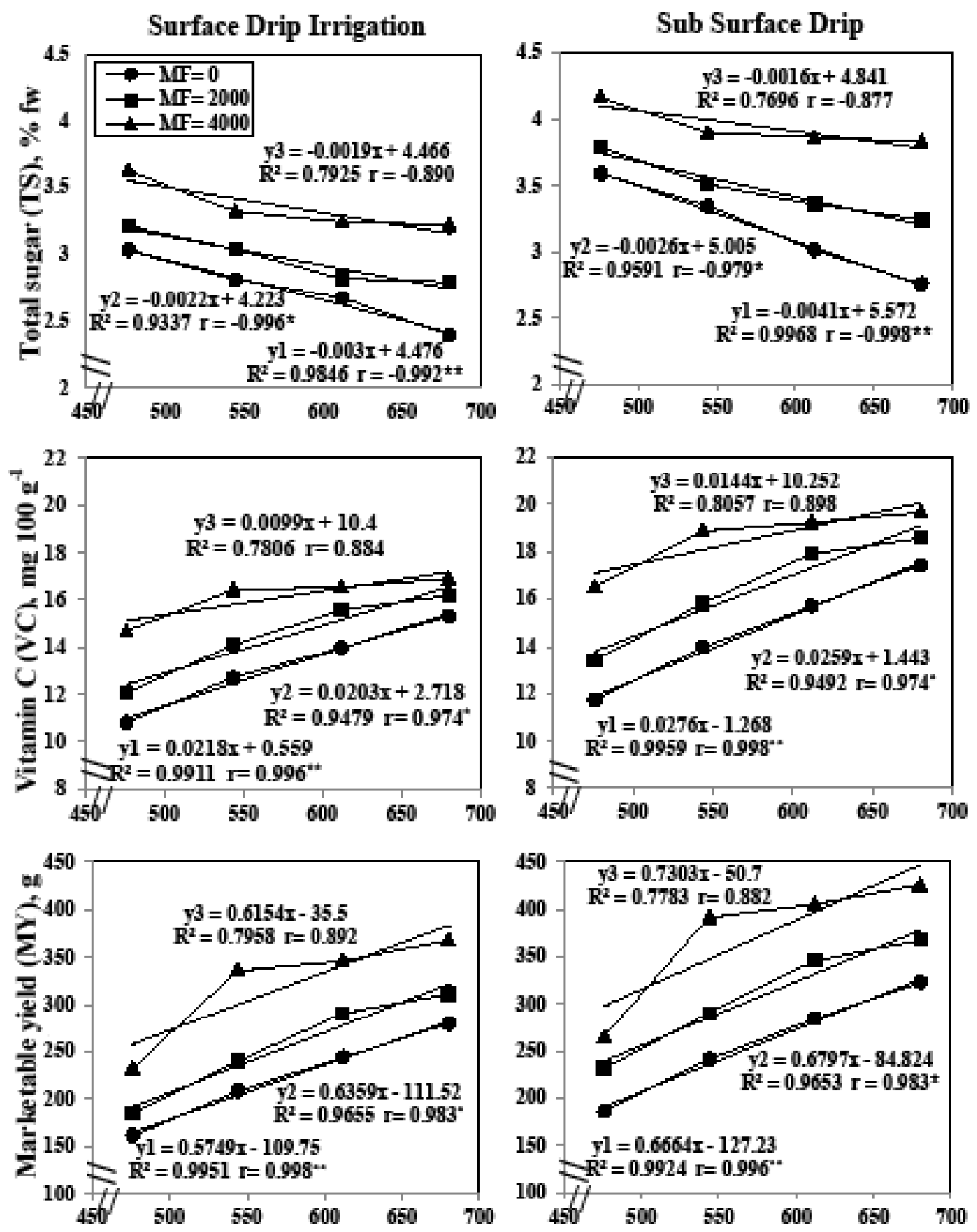

Applied irrigation water (IR), $\mathrm{mm} / \mathrm{season}$

Fig. 3. Relationships between applied irrigation water (IR) and studied quality parameters of lettuce *y1 at MF $=0$ Gauss $\quad \mathrm{y} 2$ at $\mathrm{MF}=2000$ Gauss $\quad \mathrm{y} 3$ at $\mathrm{MF}=4000$ Gauss 

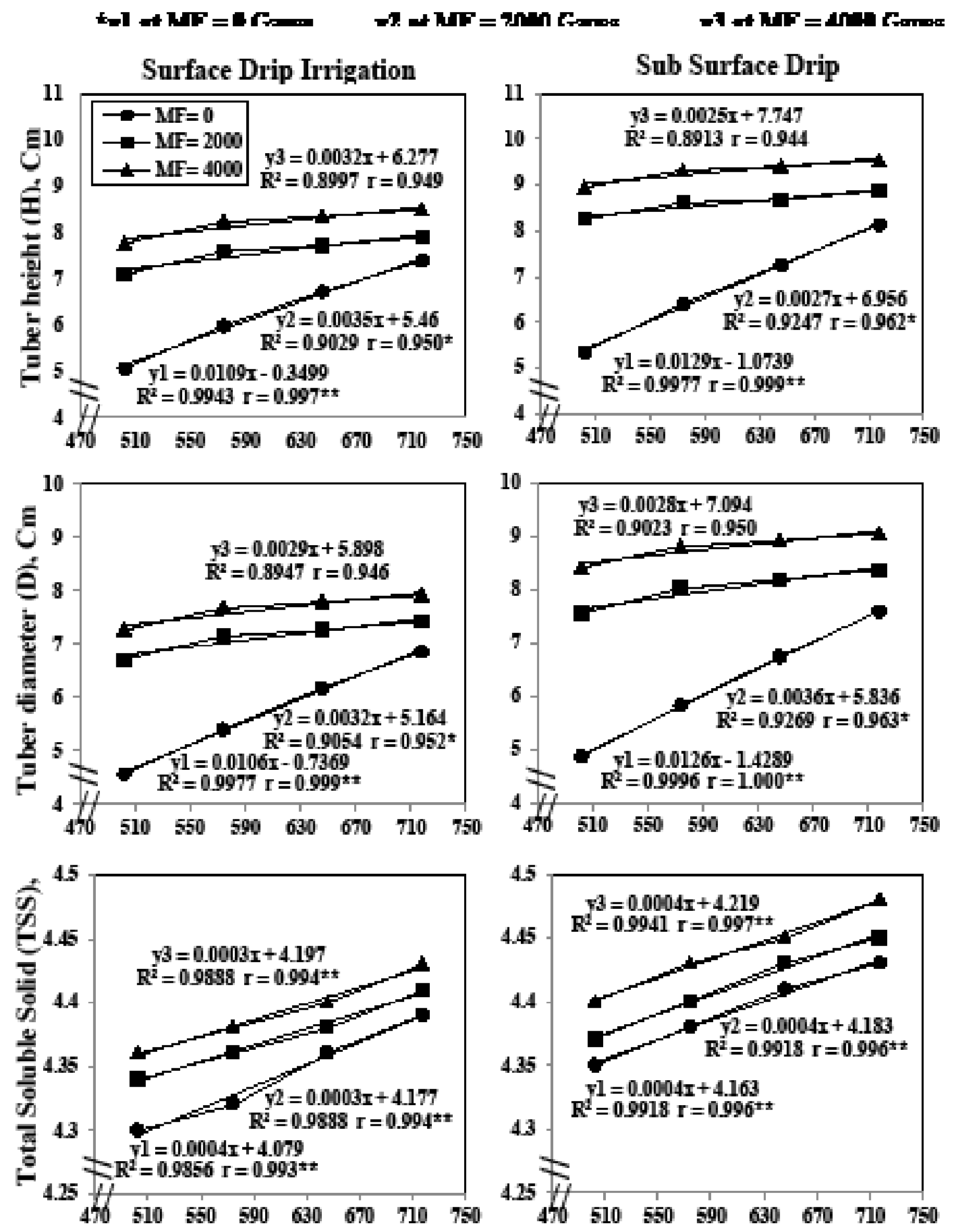

Applied irrigation water (IR), $\mathbf{m m} /$ season

Fig. 4. Relationships between applied irrigation water (IR) and studied quality parameters of Potato tuber 
TABLE 10. Effect of MF levels and IR on Ya, ETa, WUE and IWUE of lettuce plant under SDI and SSDI

\begin{tabular}{|c|c|c|c|c|c|c|}
\hline & MF & IR & Ya & ETa & WUE & IWUE \\
\hline is & (Gauas) & $(\%)$ & $\left(\right.$ Mg fed $\left.^{-1}\right)$ & $(\mathrm{mm})$ & $\left(\mathrm{Kg} \mathrm{m}^{-3}\right)$ & $\left(\mathrm{Kg} \mathrm{m}^{-3}\right)$ \\
\hline \multirow{13}{*}{ SDI } & \multirow[t]{4}{*}{ ( } & 100 & 5.84 & 511.73 & 3.20 & 2.40 \\
\hline & & 90 & 4.89 & 447.51 & 3.06 & 2.24 \\
\hline & & 80 & 3.96 & 382.65 & 2.90 & 2.04 \\
\hline & & 70 & 3.25 & 334.39 & 2.72 & 1.91 \\
\hline & \multirow{4}{*}{2000} & 100 & 6.37 & 438.69 & 4.07 & 2.62 \\
\hline & & 90 & 6.10 & 397.47 & 4.30 & 2.79 \\
\hline & & 80 & 4.92 & 371.82 & 3.71 & 2.53 \\
\hline & & 70 & 4.11 & 336.15 & 3.42 & 2.42 \\
\hline & \multirow{4}{*}{4000} & 100 & 7.00 & 406.14 & 4.83 & 2.88 \\
\hline & & 90 & 6.79 & 368.52 & 5.16 & 3.11 \\
\hline & & 80 & 6.34 & 324.16 & 5.48 & 3.26 \\
\hline & & 70 & 4.71 & 302.39 & 4.36 & 2.77 \\
\hline & \multirow{4}{*}{0} & 100 & 6.69 & 427.59 & 4.38 & 2.75 \\
\hline \multirow{11}{*}{ SSDI } & & 90 & 5.73 & 405.17 & 3.96 & 2.62 \\
\hline & & 80 & 4.81 & 371.23 & 3.63 & 2.47 \\
\hline & & 70 & 3.92 & 316.60 & 3.47 & 2.31 \\
\hline & \multirow{4}{*}{2000} & 100 & 7.53 & 374.92 & 5.63 & 3.10 \\
\hline & & 90 & 7.26 & 327.75 & 6.20 & 3.32 \\
\hline & & 80 & 5.92 & 321.26 & 5.16 & 3.05 \\
\hline & & 70 & 4.68 & 261.53 & 5.01 & 2.75 \\
\hline & \multirow{4}{*}{4000} & 100 & 8.17 & 376.37 & 6.08 & 3.36 \\
\hline & & 90 & 7.98 & 342.81 & 6.52 & 3.65 \\
\hline & & 80 & 7.54 & 298.45 & 7.08 & 3.88 \\
\hline & & 70 & 5.29 & 249.60 & 5.94 & 3.11 \\
\hline \multirow{4}{*}{ LSD (0.05) } & \multicolumn{2}{|c|}{ IS } & 0.01 & 1.96 & 0.03 & 0.01 \\
\hline & \multicolumn{2}{|c|}{$\mathrm{MF}$} & 0.01 & 3.01 & 0.03 & 0.01 \\
\hline & \multirow{2}{*}{\multicolumn{2}{|c|}{ IR }} & 0.02 & 2.56 & 0.04 & 0.01 \\
\hline & & & 0.06 & 6.80 & 0.18 & 0.03 \\
\hline
\end{tabular}

TABLE 11. Effect of MF levels and IR on Ya, ETa, WUE and IWUE of potato tuber under SDI and SSDI

\begin{tabular}{|c|c|c|c|c|c|c|}
\hline IS & $\begin{array}{c}\text { MF } \\
\text { (Gauas) }\end{array}$ & $\begin{array}{c}\text { IR } \\
(\%)\end{array}$ & $\begin{array}{c}\text { Ya } \\
\left(\mathrm{Mg} \mathrm{fed}^{-1}\right)\end{array}$ & $\begin{array}{c}\text { ETa } \\
(\mathrm{mm})\end{array}$ & $\begin{array}{c}\text { WUE } \\
\left(\mathrm{Kg} \mathrm{m}^{-3}\right)\end{array}$ & $\begin{array}{c}\text { IWUE } \\
\left(\mathrm{Kg} \mathrm{m}^{-3}\right)\end{array}$ \\
\hline \multirow{12}{*}{ SDI } & \multirow[t]{4}{*}{, } & 100 & 9.87 & 564.73 & 4.90 & 3.85 \\
\hline & & 90 & 8.35 & 496.51 & 4.71 & 3.62 \\
\hline & & 80 & 6.81 & 420.65 & 4.53 & 3.32 \\
\hline & & 70 & 5.13 & 355.42 & 4.04 & 2.86 \\
\hline & \multirow{5}{*}{2000} & 100 & 10.34 & 468.69 & 6.18 & 4.04 \\
\hline & & 90 & 9.61 & 422.47 & 6.37 & 4.17 \\
\hline & & 80 & 8.97 & 363.52 & 6.91 & 4.38 \\
\hline & & 70 & 6.89 & 332.15 & 5.81 & 3.84 \\
\hline & & 100 & 11.96 & 446.14 & 7.51 & 4.67 \\
\hline & \multirow{3}{*}{4000} & 90 & 11.32 & 403.56 & 7.86 & 4.91 \\
\hline & & 80 & 10.64 & 359.78 & 8.28 & 5.19 \\
\hline & & 70 & 9.72 & 315.62 & 8.63 & 5.42 \\
\hline \multirow{12}{*}{ SSDI } & \multirow{4}{*}{0} & 100 & 10.69 & 480.02 & 6.24 & 4.17 \\
\hline & & 90 & 9.04 & 466.46 & 5.43 & 3.92 \\
\hline & & 80 & 7.56 & 418.25 & 5.06 & 3.69 \\
\hline & & 70 & 5.71 & 347.62 & 4.60 & 3.18 \\
\hline & \multirow{4}{*}{2000} & 100 & 11.43 & 410.07 & 7.81 & 4.46 \\
\hline & & 90 & 10.58 & 359.95 & 8.23 & 4.59 \\
\hline & & 80 & 10.00 & 321.26 & 8.72 & 4.88 \\
\hline & & 70 & 7.89 & 312.17 & 7.08 & 4.40 \\
\hline & \multirow{4}{*}{4000} & 100 & 13.21 & 381.22 & 9.71 & 5.16 \\
\hline & & 90 & 12.49 & 343.02 & 10.20 & 5.42 \\
\hline & & 80 & 11.61 & 304.67 & 10.67 & 5.66 \\
\hline & & 70 & 10.57 & 262.52 & 11.28 & 5.89 \\
\hline \multirow{4}{*}{$\begin{array}{l}\text { LSD } \\
(0.05)\end{array}$} & \multicolumn{2}{|c|}{ IS } & 0.03 & 1.32 & 0.03 & 0.01 \\
\hline & \multicolumn{2}{|c|}{$\mathrm{MF}$} & 0.05 & 1.72 & 0.04 & 0.02 \\
\hline & \multicolumn{2}{|c|}{ IR } & 0.06 & 2.18 & 0.08 & 0.03 \\
\hline & \multicolumn{2}{|c|}{ IS X SL X IR } & 0.19 & 4.57 & 0.20 & 0.08 \\
\hline
\end{tabular}




\section{Gauss}

Meanwhile, the values of lettuce and potato Ya under $\mathrm{MF}=4000$ Gauss, $\mathrm{IR}=100 \%$ and SSDI treatment increased significantly by about 40 and $34 \%$ compared to those under control treatment $(\mathrm{MF}=0$ Gauss, $\mathrm{IR}=100 \%$ and SDI). This increase may be attributed to the mechanism of magnetic field with the activation of phyto-hormone such as gibberellic acidequivalents, indole-3-acetic acid and transzeatin as well as activation of the bio-enzyme systems which leads to the growth improvement and increased the crop yield. These results are in harmony with the finding of Maheshwari and Grewal (2009) and Kirnak et al. (2016).

Effect of MF and IR under IS on seasonal actual evapotranspiration

Data in Tables 10\&11 showed that the values of seasonal actual evapotranspiration ETa for lettuce and potato crops decreased with increasing MF levels. While, ETa for both crops increased with increasing IR under SDI and SSDI. The minimum values of ETa for lettuce and potato crops were 249.60 and $262.52 \mathrm{~mm}$, respectively, under $\mathrm{MF}=$ 4000 Gauss, IR=70\% and SSDI treatment. While, the maximum values were 511.73 and $564.73 \mathrm{~mm}$ for both crops under control treatment $(\mathrm{MF}=0$ Gauss, $\mathrm{IR}=100 \%$ and SDI). These results agree with Aoda and Fattah (2011).

\section{Effect of MF and IR under IS on WUE and IWUE: Lettuce}

Data in Table 10 concluded that the maximum values of water use efficiency (WUE) and irrigation water use efficiency (IWUE) for lettuce plant were 7.08 and $3.88 \mathrm{~kg} \mathrm{~m}^{-3}$, respectively, under $\mathrm{MF}=4000$ Gauss, $\mathrm{IR}=80 \%$ and SSDI treatment. While, the minimum values were 2.72 and 1.91 $\mathrm{kg} \mathrm{m}^{-3}$,respectively, for both crops under $\mathrm{MF}=0$ Gauss, $I R=70 \%$ and SDI treatment. Meanwhile, the values of WUE and IWUE under $\mathrm{MF}=4000$ Gauss, IR $=80 \%$ and SSDI treatment increased significantly by about 121 and $62 \%$, respectively, compared to those under control treatment $(\mathrm{MF}=0$ Gauss, IR $=100 \%$ and SDI). These results may be attributed to that the marketable yield for lettuce plant increased with increasing MF levels for all treatments. While, ETa and IR decreased with increasing MF levels for all treatments. These results were similar to those reported by Aoda and Fattah (2011) and Kirnak et al. (2016).

\section{Potato}

Egypt. J. Soil Sci. 57, No. 3 (2017)
Data in Table 11 reported that the maximum values of WUE and IWUE for potato tuber were 11.28 and $5.89 \mathrm{~kg} \mathrm{~m}^{-3}$, respectively, under $\mathrm{MF}=$ 4000 Gauss, $I R=70 \%$ and SSDI treatment. While, the minimum values were 4.04 and $2.86 \mathrm{~kg} \mathrm{~m}^{-3}$ for both crops under $\mathrm{MF}=0$ Gauss, $\mathrm{IR}=70 \%$ and SDI treatment. Meanwhile, the values of WUE and IWUE under $\mathrm{MF}=4000$ Gauss, $\mathrm{IR}=70 \%$ and SSDI treatment increased significantly by about 130 and $53 \%$, respectively, compared to that under control treatment (MF $=0$ Gauss, $\mathrm{IR}=100 \%$ and SDI). These results are in harmony with the finding of Ayas (2013) and Ahmed and Abd ElKader (2016)

$I R$ and SL on crop yield response factor (Ky):Lettuce

Data in Fig. 6 showed that the crop yield response factor $(\mathrm{Ky})$ for lettuce indicates a linear relationship between the relative reduction in actual evapotranspiration 1-(ETa/ETmax) and the relative reduction in yield $1-(\mathrm{Ya} / \mathrm{Ymax})$. These relationships recorded that they highly significant positively correlated with $\mathrm{MF}=0$ Gauss, $\left(\mathrm{r}=1.000^{* *}\right)$ and $\left(\mathrm{r}=0.996^{* *}\right)$ at different IR under SDI and SSDI, respectively. Also, the same relationships showed that they significantly positively correlated with $\mathrm{MF}=2000$ Gauss, $(\mathrm{r}=$ $\left.0.955^{*}\right)$ and $\left(r=0.953^{*}\right)$ at different IR under SDI and SSDI , respectively. Finally, the relationships between 1-(ETa/ETmax) and 1-(Ya/Ymax) of lettuce plant were not significantly correlated with $\mathrm{MF}=4000$ Gauss, at different IR under SDI and SSDI ; these results agree with Aoda and Fattah (2011). Moreover, Fig. 7 revealed that the values of Ky for lettuce decreased with increasing both MF levels and IR under SDI and SSDI irrigation. The maximum value of $\mathrm{Ky}$ for lettuce plant was 1.12 under $\mathrm{MF}=0$ Gauss, $\mathrm{IR}=70 \%$ and SDI treatment. While, the minimum value was 0.06 under $\mathrm{MF}=$ 4000 Gauss, IR=90\% and SSDI treatment. The same figure showed that the relationships between IR, mm and $\mathrm{Ky}$ of lettuce plant were high significantly negatively correlated with $\mathrm{MF}=0$ Gauss, $(\mathrm{r}=-0.994 * *)$ and $(\mathrm{r}=-0.992 * *)$ under SDI and SSDI, respectively. While, the same relationships recorded that they significantly negatively correlated with $\mathrm{MF}=2000$ Gauss, $\left(\mathrm{r}=-0.975^{*}\right)$ and $\left(\mathrm{r}=-0.973^{*}\right)$ under SDI and SSDI , respectively. Meanwhile, the relationships between IR, mm and Ky of lettuce plant were not significantly correlated with $\mathrm{MF}=4000$ Gauss, under SDI and SSDI. These results were similar to those reported by Kirnak et al. (2016). 

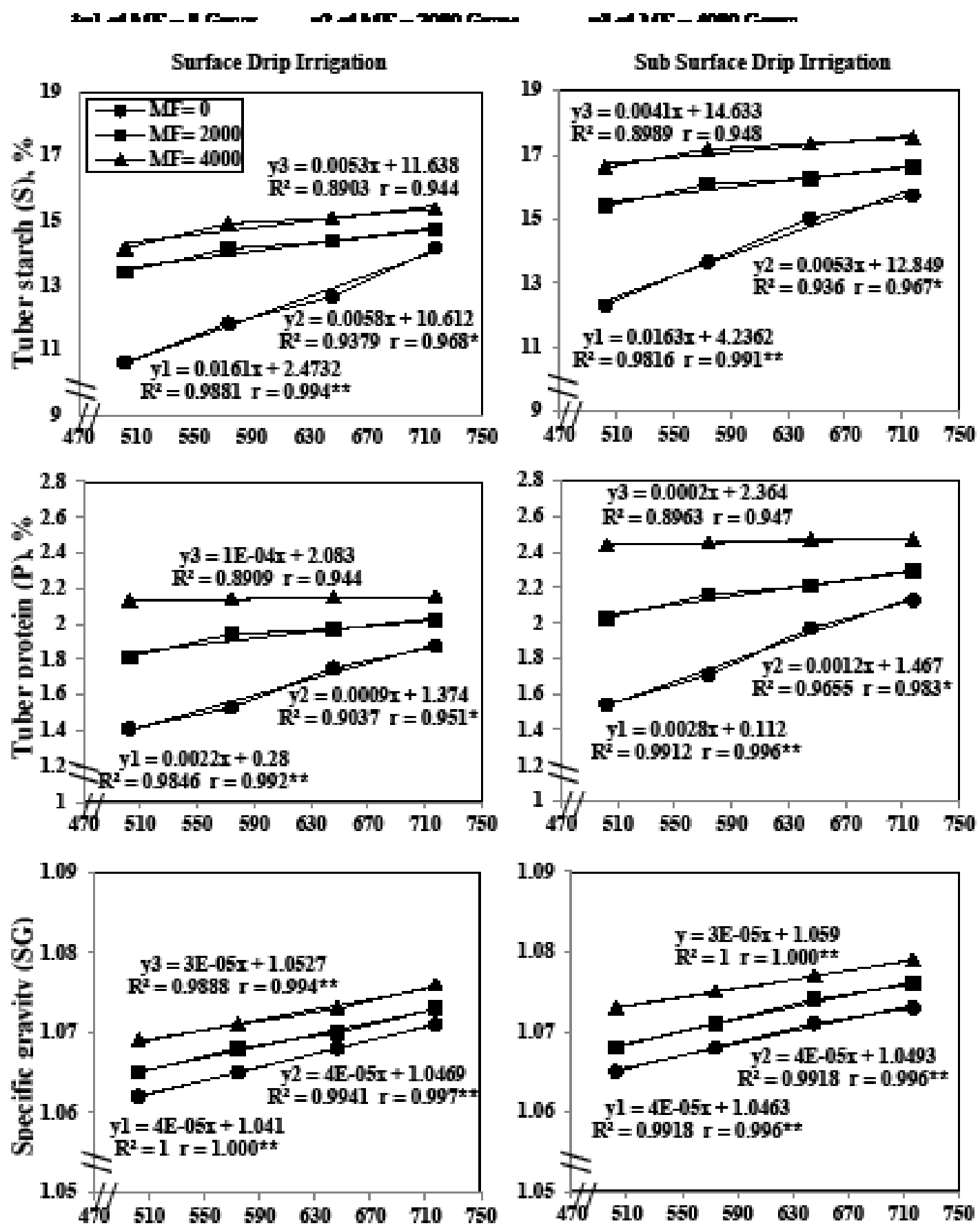

Applied irrigation water (IR), mm/season

Fig.5. Relationships between applied irrigation water (IR) and studied quality parameters of Potato tuber 

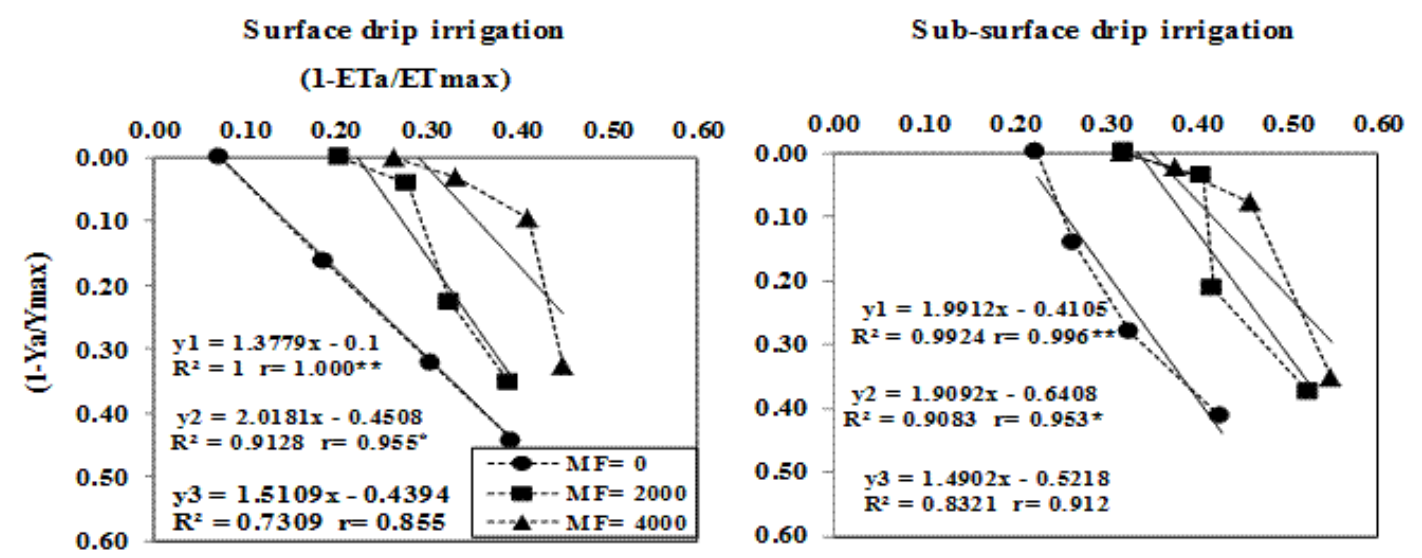

Fig. 6. The relation ship between a decrease in marketable yield (Ya) and crop evapotranspiration (ETc) deficit for lettuce plant
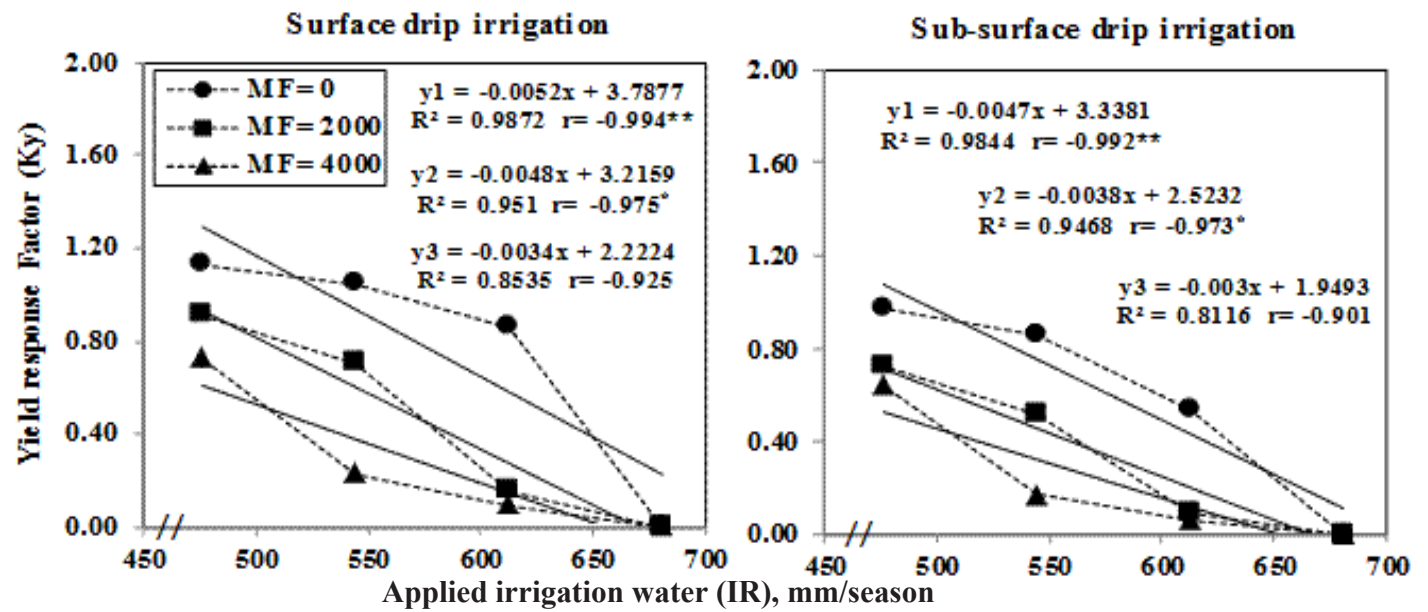

Fig. 7. Effect of magnetic field (MF) at different applied irrigation water (IR) on yield response factor (Ky) for lettuce plant

\section{Potato}

Data in Figure 8 reported that the relationships between 1-(ETa/ETmax) and 1-(Ya/Ymax) for potato tuber were high significantly positively correlated with $\mathrm{MF}=0$ Gauss, $(\mathrm{r}=0.994 * *)$ and $\left(\mathrm{r}=0.998^{* *}\right)$ at different IR under SDI and SSDI respectively. Also, the same relationships showed that they significantly positively correlated with $\mathrm{MF}=2000$ Gauss, $\left(\mathrm{r}=0.974^{*}\right)$ and $(\mathrm{r}=0.972 *)$ at different IR under SDI and SSDI, respectively. Finally, the relationships between 1-(ETa/ETmax) and $1-(\mathrm{Ya} / \mathrm{Ymax})$ of potato tuber were not significantly correlated with $\mathrm{MF}=4000$ Gauss, at different IR under SDI and SSDI. Moreover, Fig. 9 showed that the values of Ky for potato decreased with increasing both MF levels and IR under SDI and SSDI irrigation. The maximum value of $\mathrm{Ky}$ for potato tuber was 1.23 under $\mathrm{MF}=$
0 Gauss, $\mathrm{IR}=70 \%$ and SDI treatment. While, the minimum value was 0.13 under $\mathrm{MF}=4000$ Gauss, $\mathrm{IR}=90 \%$ and SSDI treatment.

The same figure showed that the relationships between IR, $\mathrm{mm}$ and Ky of potato tuber were high significantly negatively correlated with $\mathrm{MF}=0$ Gauss, $\left(\mathrm{r}=-0.996^{* *}\right)$ and $\left(\mathrm{r}=-0.999^{* *}\right)$ under SDI and SSDI, respectively. While, the same relationships recorded that they significantly negatively correlated with $\mathrm{MF}=2000$ Gauss, $\left(\mathrm{r}=-0.967^{*}\right)$ and $(\mathrm{r}=-0.962 *)$ under SDI and SSDI, respectively. Meanwhile, the relationships between IR, mm and Ky of potato tuber were not significantly correlated with $\mathrm{MF}=4000$ Gauss, under SDI and SSDI. These results agree with AlJanaby (2012). 
S urface drip irrigation

(1-ETa/ETmax)

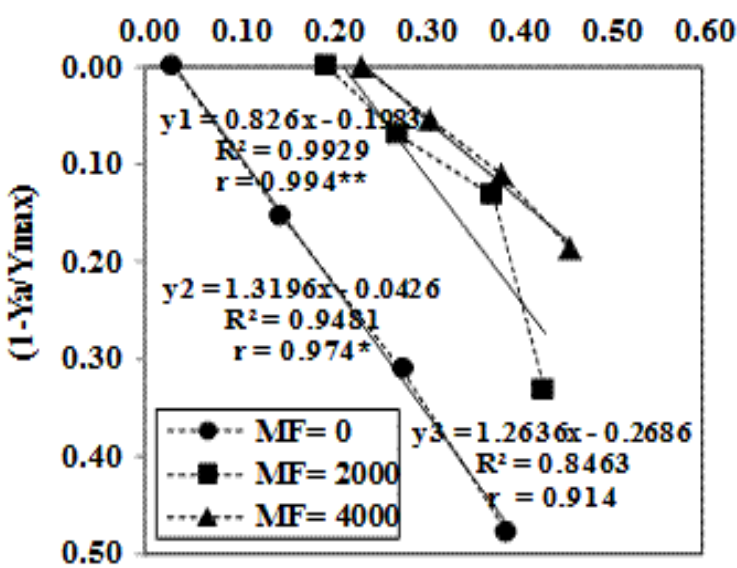

Sub-surface drip irrigation

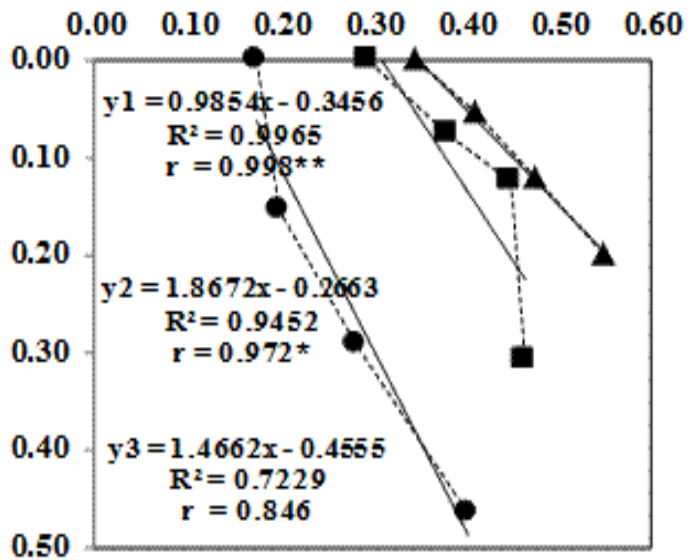

Fig. 8. The relation ship between a decrease in marketable yield (Ya) and crop evapotranspiration (ETc) deficit for lettuce plant
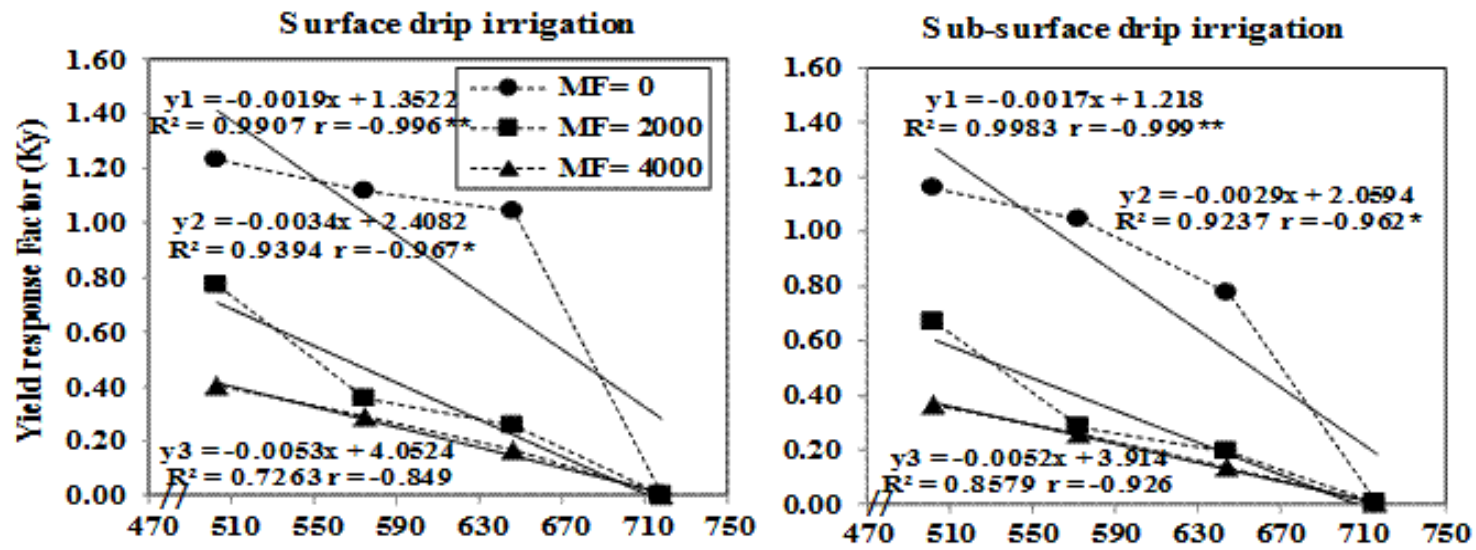

Fig. 9. Effect of magnetic field (MF) at different applied irrigation water (IR) on yield response factor (Ky) for Potato tuber

\section{Conclusion}

Results of the current study demonstrated beneficial effects, of MF levels and IR under SDI and SSDI on the Ya, studied quality parameters, seasonal ETa, WUE, IWUE and Ky for lettuce plant and potato tuber under Egyptian sandy soil. This study concluded that:

1. The values of physical analyses of irrigation water decreased with increasing MF levels except solubility. While, the values of chemical analyses of IR increased with increasing MF levels except SAR. Meanwhile, the values of $\left(\mathrm{Na}^{+}, \mathrm{K}^{+}, \mathrm{CL}^{-}\right.$and
$\mathrm{HCO}_{3}^{-}$) were not significant at different $\mathrm{MF}$ levels.

2. The values of quality parameters for lettuce plant and potato tuber increased with increasing both MF levels and IR under SDI and SSDI except total sugar TS for plant lettuce. The relationships between IR, $\mathrm{mm}$ and studied quality parameters of lettuce plant and potato tuber were not significantly correlated with $\mathrm{MF}=4000$ Gauss, under SDI and SSDI.

3. The maximum values of Ya for lettuce and potato crops were 8.17 and $13.21 \mathrm{Mgfed}^{-1}$ respectively, under $\mathrm{MF}=4000$ Gauss, $\mathrm{IR}=100 \%$ and SSDI treatment.

Egypt. J. Soil Sci. 57, No. 3 (2017) 
4. The values of ETa for lettuce and potato crops decreased with increasing MF levels. While, ETa for both crops increased with increasing IR under SDI and SSDI.

5. The values of WUE and IWUE for lettuce plant under $\mathrm{MF}=4000$ Gauss, $\mathrm{IR}=80 \%$ and SSDI treatment increased significantly by about 121 and $62 \%$, respectively, compared to those under control treatment. While, The values of WUE and IWUE for potato tuber under $\mathrm{MF}=4000$ Gauss, $\mathrm{IR}=70 \%$ and SSDI treatment increased significantly by about 130 and $53 \%$, respectively compared to those under control treatment.

6. Finally, the minimum values of $\mathrm{Ky}$ of lettuce and potato tuber were 0.06 and 0.13 , respectively, under $(\mathrm{MF}=4000$ Gauss, $\mathrm{IR}=90 \%$ and SSDI) treatment compared to that 0.00 under control treatment.

So, it is recommended to use $(\mathrm{MF}=4000$ Gauss at $\mathrm{IR}_{80 \%}$ under SSDI) treatment for Ya of lettuce plant. This treatment could save about $20 \%$ of irrigation water and increased significantly by about $29 \%$ compared to that under control treatment. While, $(\mathrm{MF}=4000$ Gauss at $\mathrm{IR}_{70 \%}$ under SSDI) treatment for Ya of potato tuber could save about $30 \%$ of irrigation water and increased significantly by about $7 \%$ compared to that under control treatment. This means that this technology can be recommended to farmers to improve their production and save irrigation water.

\section{References}

Al-Khazan, M., Abdullatif, B.M. and Al-Assaf, N., (2011) Effects of magnetically treated water on water status, chlorophyll pigments and some elements content of Jojoba (Simmondsia chinensis L.) at different growth stages. African Journal of Environmental Science and Technology, 5(9), 722731.

Allen, R.G., Smith, M.; Perrier, A. and Pereira, L.S. (1998) Crop Evapotranspiration, guidelines for computing crop water requirements. FAO Irrigation and Drainage Paper No.56, FAO, Rome, Italy: 1-79.
Al-Janaby, M.A. (2012) Effect of drip irrigation, organic manure and mulching on growth and yield of potato. (Solanum tuberosum L.). Ph D. Thesis. College of Agriculture. University of Baghdad: 133.

Amer, M.M., El Sanat, A.G. and Rashed S. H. (2014) Effects of magnetized low quality irrigation water on some soil properties and soybean yield (Glycine Max L.) under salt affected soils conditions. J. Soil Sci. and Agric. Eng., Mansoura Univ. 5 (10), 1377 - 1388.

Aoda, M.I. and Fattah, M.A. (2011) The interactive effects of water magnetic treatment and deficit irrigation on plant productivity and water use efficiency of corn (zea mays L.). The Iraqi Journal of Agricultural Sciences, 42 (Special Issue),164-179.

Ayas, S. (2013) The effects of different regimes on potato (Solanum tuberosum L. Hermes) yield and quality characteristics under unheated greenhouse conditions. Bulg. J. Agric. Sci., 19, 87-95.

Ayers, R.S. and Westcot, D.W. (1994) Water Quality for Agriculture, Irrigation and Drainage Paper No 29, FAO, Rome, Italy.

Charan, R. (2009) Effect of stimulating magnetic field on plants. Indian J. Theor. Phys., 57, 15-20.

Doorenbos, J. And Pruitt, W.O. (1984) Crop Water requirements - Guidelines for predicting crop requirements. FAO Irrigation and Drainage Paper No.24, FAO, Rome, Italy: 45-90.

Dogras, C., Siomos, A. and Psomakelis, C. (1991) Sugar and dry matter changes in potatoes stored in a clamp in a mountainous region of Northern Greece. Potato Research, 34, 211-214.

Hasaani, A.S., Hadi, Z.L. and Rasheed, K.A. (2015) Experimental study of the interaction of magnetic fields with flowing water. International Journal of Basic and Applied Science, 3(3),1-8.

Howell, T.A. (2001) Enhancing water use efficiency in irrigated agriculture. Agronomy J. Abst., 93, 281 - 289.

Keller, J. and Karmeli, D. (1974) Trickle irrigation design parameters. ASAE, 17 (4), 678-684.

Kirnak, H., Taş I., Gökalp, Z. and Karaman, S. (2016) Effects of different irrigation levels on yield of lettuce grown in an unheated greenhouse. Current 
Trends in Natural Sciences, 5(9):145-151.

Klute, A. (1986) Methods of soil Analysis, Part (1). Physical and Mineralogical Methods-Agronomy monograph No. 9 ( $2^{\text {nd }}$ edition). ASA and SSSA, Madison, WI, USA: $635-660$.

Maheshwari, B. L. and Grewal, H. S. (2009) Magnetic treatment of irrigation water: Its effects on vegetable crop yield and water productivity.Agricultural Water Management, 96, 1229-1236.

Michael, A. (1978) Irrigation and Theory Practice. Vikas Pub. House PVT LTD, New Delihi.

Nissen, M. (1967) The weight of potatoes in water: further studies on the relation between the dry matter and starch content. Eur. Potato J., 10 (2), 85-99.

Page, A.L., Miller, R.H. and Keeney, D.R. (1982) Methods of soil Analysis, part 2. Chemical and Microbiological Properties. Amer. Soc. of Agron, Madison, Wisconsin, USA.

Smith, M. (1992) CROPWAT A Computer Program for Irrigation Planning and Management and ETo calculation using Penman-Montieth method, FAO Irrigation and Drainage, Rome, Italy: 46, 112-140.

Shahin, M.M., Mashhour, A.M. and A bd-Elhady, E. S. (2016) Effect of Magnetized Irrigation Water and Seeds on Some Water Properties, Growth Parameter and Yield Productivity of Cucumber Plants. Current Science International 5 (2), 152-164.

Snedecor, G.W. and Cochran, W.G. (1989) Statistical Methods, $8^{\text {th }}$ ed., Iowa State Univ. Press, Iowa. USA: 476.

Strasak, L., Veterl, V. and Smarda, J. (2002) Effects of low frequency magnetic fields on bacteria Escherichia coli. Bio electrochemistry, 55(1-2), 161-164.

Yano, A., Ohashi, Y., Hirasaki, T. and Fujiwara, K. (2004) Effects of $60 \mathrm{~Hz}$ magnetic field on photosynthetic uptake and early growth of radish seedlings. Bio Electromagnetics, 25(8), 572-581.

(Received:29/12 /2016; acecpted:19/3 / 2017) 


\section{رفع كفاءة الأستهلاك المائى لبعض النباتات بتقنية الماء المعالج مغناطيسيا تحث ظروف شرق العوينات

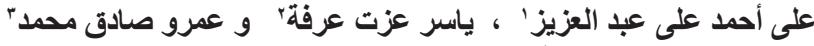

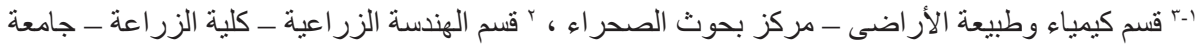

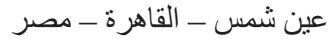

‘أجريت هذه التجربة في منطقة شرق العوينات بمحافظة الوادى الجديد - جمهورية مصر العربية وكانت

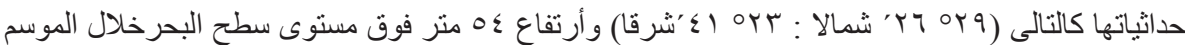

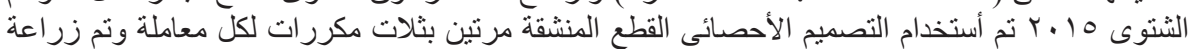

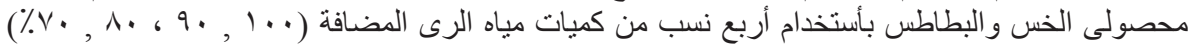

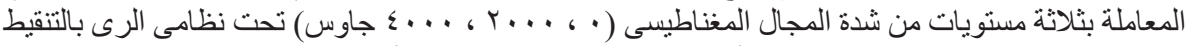

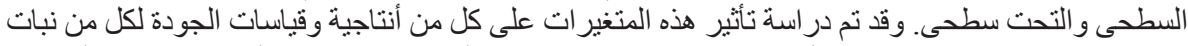

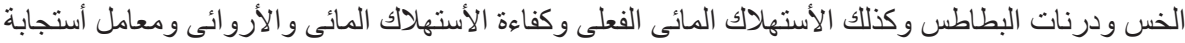

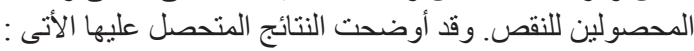

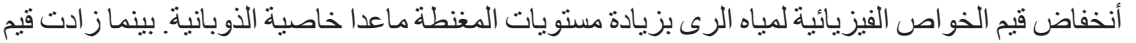

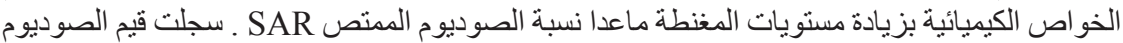

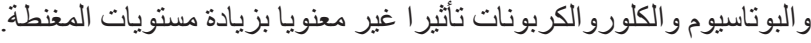

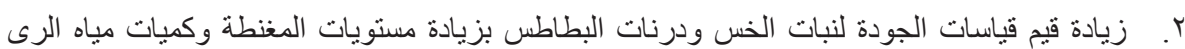
المضافة تحت نظامى الرى بالتنقيط السطحى و التحت سطحى ماعدا السكريات الكلية لنبات الخسات الخس.

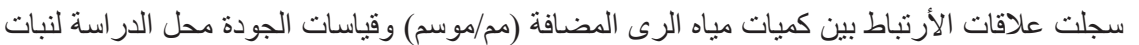

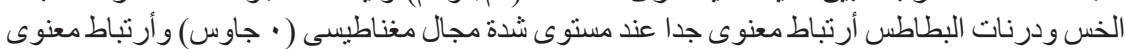

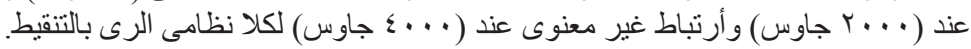

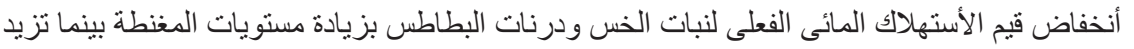

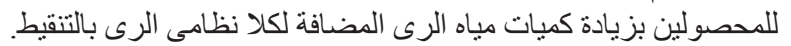

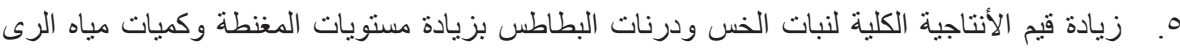

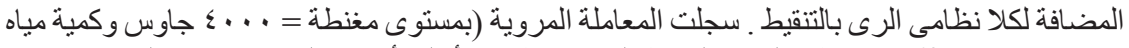

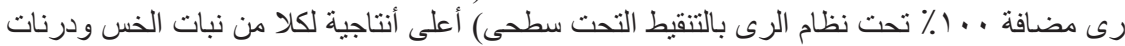

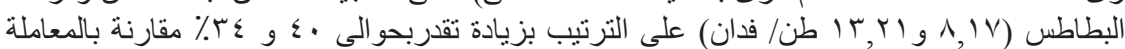

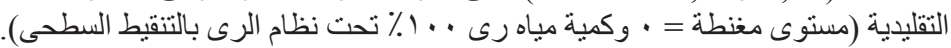

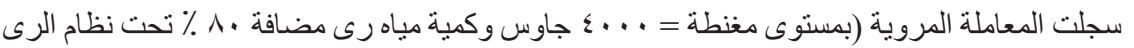

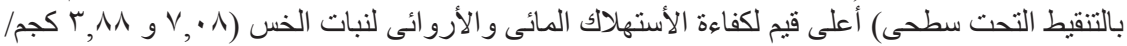

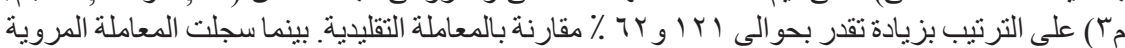

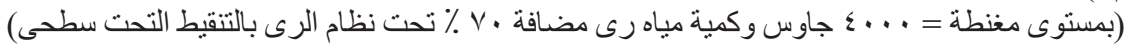

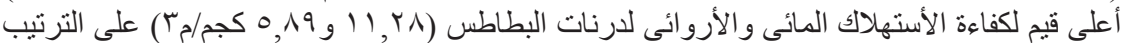

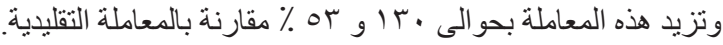

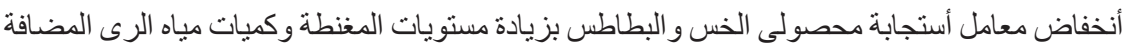

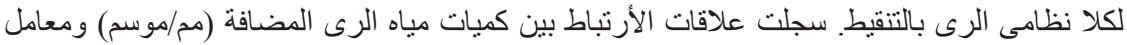

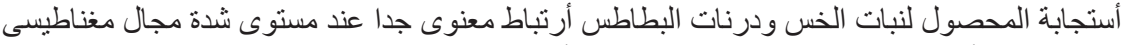

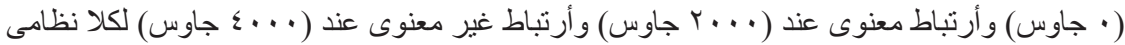

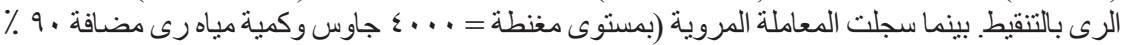

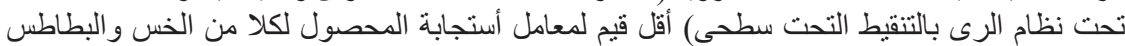

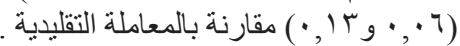

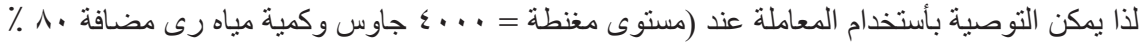

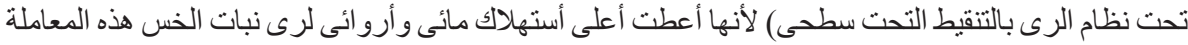

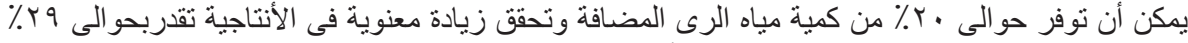

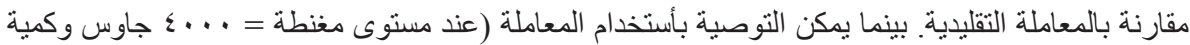

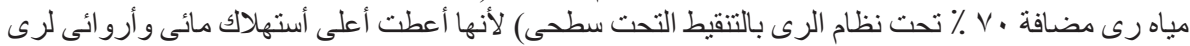

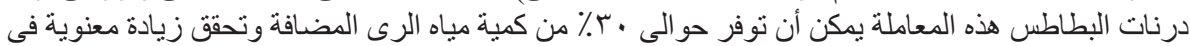

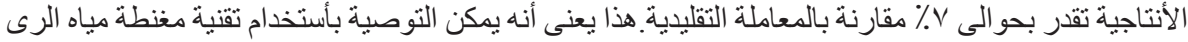

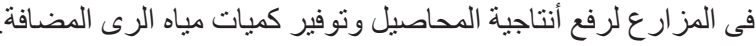

Egypt. J. Soil Sci. 57, No. 3 (2017) 